\title{
A study of radon and thoron concentration in the soil along the active fault of NW Himalayas in India
}

\author{
Gulshan Kumar ${ }^{1,4}$, Punam Kumari ${ }^{1}$, Arvind Kumar ${ }^{2}$, Sangeeta Prasher ${ }^{3}$, Mukesh Kumar ${ }^{1}$ \\ 1 Department of Physics, Lovely Professional University, Phagwara, Punjab, India \\ 2 National Center for Research on Earthquake Engineering, Taipei, Taiwan \\ 3 Department of Physics, Kanya Maha Vidyalaya, Jalandhar, Punjab, India \\ ${ }^{4}$ Govt. College, Sarkaghat, Mandi, Himachal Pradesh, India
}

\section{Article history}

Received May 18, 2016; accepted March 01, 2017.

Subject classification:

Radon concentration, Lithological locations, Active fault line, Main Boundary Thrust.

\begin{abstract}
The Study has been conducted to analyse the radon and thoron flux in the soil of Mandi district, Himachal Pradesh. The detectors have been rooted at seventy one lithological locations in the north-eastern part of the district. The average values of radon concentration has been observed as $4541 \mathrm{~Bq} / \mathrm{m}^{3}$ with maximum of $19970 \mathrm{~Bq} / \mathrm{m}^{3}$ at location no. 3 ( $N 32^{\circ} 00.46^{\prime}:$ E $\left.76^{\circ} 51.74^{\prime}\right)$ and minimum of $867 \mathrm{~Bq} / \mathrm{m}^{3}$ at location no. 57 (N 31 ${ }^{\circ} 45.65^{\prime}:$ E 76 $\left.{ }^{\circ} 51.56^{\prime}\right)$ and the thoron variation ranges from 37 to $6970 \mathrm{~Bq} / \mathrm{m}^{3}$ with an average value of $1778 \mathrm{~Bq} /$ $\mathrm{m}^{3}$. The radon liberation at different positions has been correlated to the presence of the active fault to reveal the contributory aspects for abnormal release of radon in the soils. The spatial distribution of radon and thoron gas along the lines passing through the fault zones have unveiled the variances connected to the local tectonic structures. Radon exhalation rates, radium contents and porosity of soil samples have been calculated and a correlation factor of 0.64 has been detected for the observed concentrations of thoron and the porosity of the soil.
\end{abstract}

\section{Introduction}

Himalayan mountains are one of the most seismically active fault zones in the world. The monitoring of soil gases like hydrogen, helium, radon- thoron, methane, carbon dioxide profiles in these zones may provide useful information before the seismic activities. Anomalous changes in the subsurface soil gas concentrations may be used as tectonic activities precursor according to the dilitancy-diffusion model for earthquake occurrence [Scholz et al. 1973]. Moreover the soil gas monitoring has been developed as the effective tool in understanding the gas transportation mechanisms in the seismically active zones and many other fields of geosciences. However, the precursor predictions may not be accurate, but may be helpful to study the under soil activities [Han et al. 2014] and is considered as precursor for various deportation processes, such as to discover fault interfaces and uranium- thorium ores [Quattrocchi et al. 2000]. Improved permeability of soils along active faults customarily favours the gas escape, hydraulic conductivity (for ground water and thermal fluids), however the thermal conductivity of the soil decreases with increase in the porosity and permeability of soil because the pore filling fluids have lower value of coefficient of thermal conductivity [Poelchau et al. 1997]. The movement of radon through rocks under the earth largely depends on lithology, compaction, porosity and fractural/tectonic features [Choubey et al. 1997, Gunderson et al. 1998]. The presence of various fault systems and thrusts in any region provides secondary porosity for upward migration of thermal fluids. The thermal gradient may be diluted if fresh water is mixed in up flow of thermal fluid [Sharma 1977, Shanker 1988, Cinti et al. 2009].

Gas anomalies at active faults can be either 'direct leak anomalies' where the gas measured corresponds to the deep gas phase or 'secondary anomalies linked to different mineralogy having only superficial roots like the anomalous distribution of radium [Toutain and Boubron 1999]. The measurement of various soil gases for earthquake monitoring and prediction of active faults zones has been reported by various researchers. [Etiope and Lombardi 1995, Igarashi et al. 1995, Ciotoli et al. 1998, Guerra and Lombardi 2001, Al-Tamimi and Abumurad 2001, Chyi et al. 2005, Fu et al. 2005, Singh et al. 2005, Kumar et al. 2009, 2012, 2013a, 2013b, Pereira et al. 2010, Singh et al. 2010, Sac et al. 2011, Yang et al. 2011, Li et al. 2013, Walia et al. 2013, Koike et al. 2014, Han et al. 2014, Jaishi et al. 
2014, Jashank, 2014, Georgy et al. 2015, Piersanti et al. 2015]. Measurement of natural radon in soil is very important to determine because it helps in monitoring changes in natural background activity with time as a result of any radioactivity release [Darko et al. 2015]. The soil gas and water radon has been measured using alpha guards in some areas of Punjab and Himachal Pradesh for health risk assessments [Bajwa et al. and Walia et al. 2003].

Chandrasekharam et al. [2005] and Walia et al. [2005] have conducted studies of the Himachal Pradesh geothermal sub-province mainly on the famous thermal springs of Manikaran and Kasol along the Parvati with the aim to characterize the geothermal re- sources with respect to their suitability for electric power production. Other study by various authors [Choubey et al. 1997, 2007, Virk and Walia 2000, Walia et al. 2003] focused on radon monitoring in waters and soils for health hazard assessment and earthquake prediction research. Some research papers have reported chemical [Gupta 1996] and isotopic data [Giggenbach et al. 1983] of the thermal waters.

The present studies dealt with radon-thoron measurements in soils, measurement of radon exhalation rates and radium contents of Mandi district, Himachal Pradesh, NW Himalaya, India using the passive detectors LR -115 type 2 films and measurement of porosity of soil samples from sampling sites. The technique

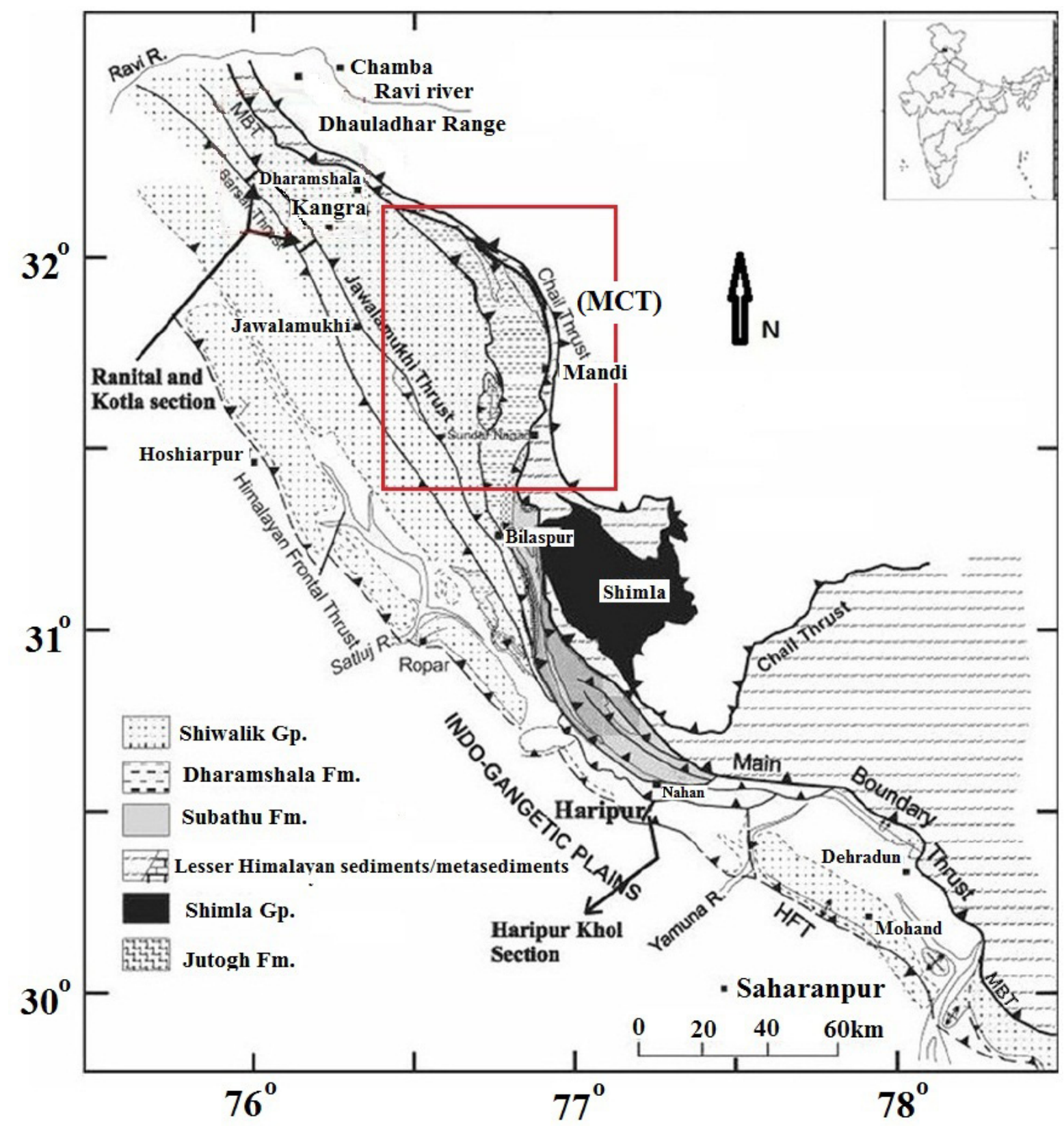

Figure 1. Geological map of the study area. 


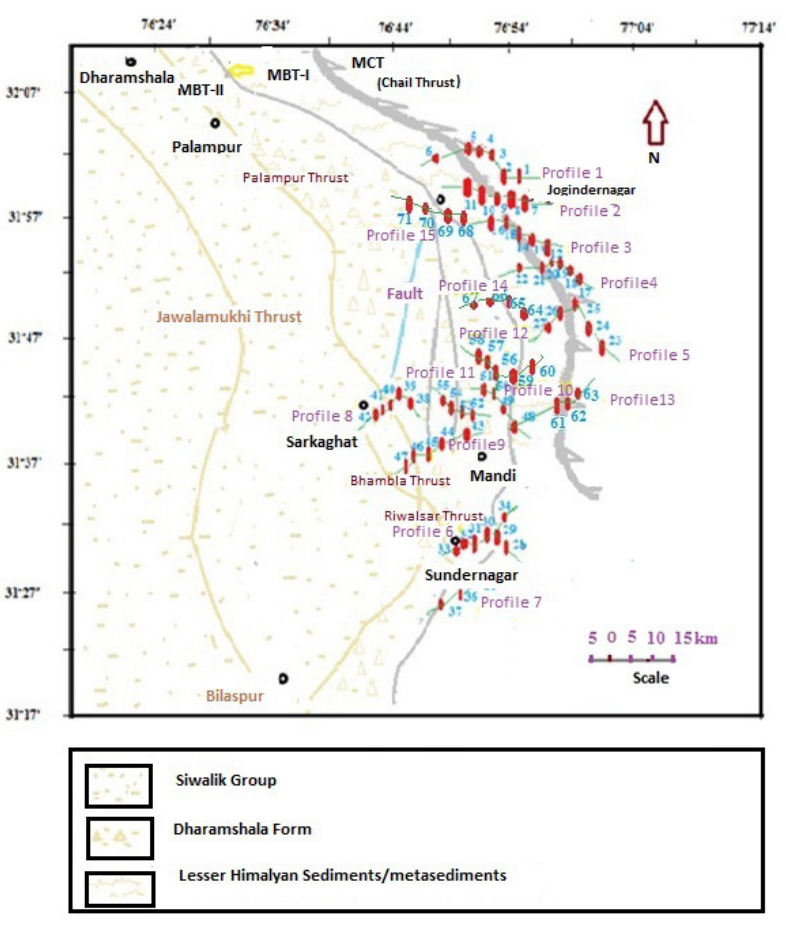

Figure 2. The position of the detectors installed along different faults and thrust system in the study area.

used is cost effective, easily applicable and less disturbed by different environmental conditions. The statistical variation in measurement of radon concentration is larger in summer than in winter [Szabo et al. 2013] keeping in view this fact, study was performed in January and February, 2015

\section{Geological Mapping of study Area}

The study area is Mandi $\left(31^{\circ} 13^{\prime} 26^{\prime \prime}-32^{\circ} 04^{\prime} 22^{\prime \prime}\right.$ north latitude and $76^{\circ} 36^{\prime} 08^{\prime \prime}-70^{\circ} 23^{\prime} 26^{\prime \prime}$ east longitude) that includes the various thrust and fault systems especially MBT (Main boundary thrust), Chail thrust, Palampur thrust, Galma thrust, Riwalsar thrust and various fault systems (Figure 1). These faults and thrust are formed because of collision of Indian and Eurasian converging Plates [Gansser 1964]. This district lies partly on rocks belonging to the central Himalayan zone some part of district lies on tertiary shale and sand stone. Rocks of area represent the Paleoproterozoic period and are strongly foliated with well-developed augen-gneiss, Sericite- chlorite, carbonaceous slates with lime stone residues, Phyllite quartzite, mylonitic gneiss and Porphyroblastic biotite gneiss with non-foliated granitoids. These types of Geological formations near MCT are cause of some geothermal regions in Himachal Pradesh. The high intensity of Thermal energy $\left(>100 \mathrm{~mW} / \mathrm{m}^{2}\right)$ with temperature gradient of more than $200^{\circ} \mathrm{C} / \mathrm{km}$ have been observed at some places in north west Himalaya [Shanker 1988]. The areas where aquifers are situated near to earth surface geothermal sources like, Manikaran in Kullu and Tatapani in Mandi district formed. Whereas micaceous purple clay and silt with intrusive granite are found near MBT. The region under study has a good average rainfall (about $1331.5 \mathrm{~mm}$ as compare to Himachal Pradesh's average of $1251 \mathrm{~mm}$ ) including more than $2000 \mathrm{~mm}$ in the Jogindernagar belt hence a good quantity of the fresh water is seeped to the ground, when this feature is added to high porosity at certain places, unconfined aquifers situation is formed, which causes the elevated ground water levels around MCT and MBT in Mandi district [Walia et al. 2005, Chandrasekharam et al. 2008]. These are the oldest rocks exposed in Himachal Pradesh comprises dominantly of purple coloured arenaceous sediments with argillites and characterized by interstratified basic lava flows of the Mandi-Darla Volcanic [Geology and Mineral resources of Himachal Pradesh, 2012].

\section{Material and Methods}

2.1 Measurements of the radon and thoron concentration in soil

Polyvinyl chloride pipe of length $0.25 \mathrm{~m}$ and diameter of $0.06 \mathrm{~m}$ with an air tight aluminium caps at the ends has been used as discriminator for the radon-thoron. The detectors LR -115 type -2 films were cut in to the pieces of size of $0.015 \mathrm{~m} \times 0.015 \mathrm{~m}$ and placed at the bottom and top of the discriminator to record alpha particle tracks of thoron and radon and radon, respectively. Figure 2 shows the position of the detectors along with different faults and thrust systems in the study area, whereas figure 3 shows the sketch of radon thoron discriminator used at 71 selected sites in the study area.

After exposure to standard durations of 15 days the detectors were subjected to chemical processing in a $10 \mathrm{M}$ analytical grade sodium hydroxide solution at $(60 \pm 1)^{\circ} \mathrm{C}$, for $90 \mathrm{~min}$, in a constant temperature water bath to enlarge the latent tracks produced by alpha particles. The washed and dried detectors were observed under an optical microscope (Zeiss at $400 \times$ magnification) to count the alpha particle tracks. The counted tracks have been converted in to units of radon concentration of $\mathrm{Bq} / \mathrm{m}^{3}$ using calibration factor [Eappen and Mayya 2004].

2.2 Measurement of the radon exhalation rates and porosity from soil samples

The soil samples collected from 71 different sites of study area (Figure 2) have been dried and grinded 
KUMAR ET AL.

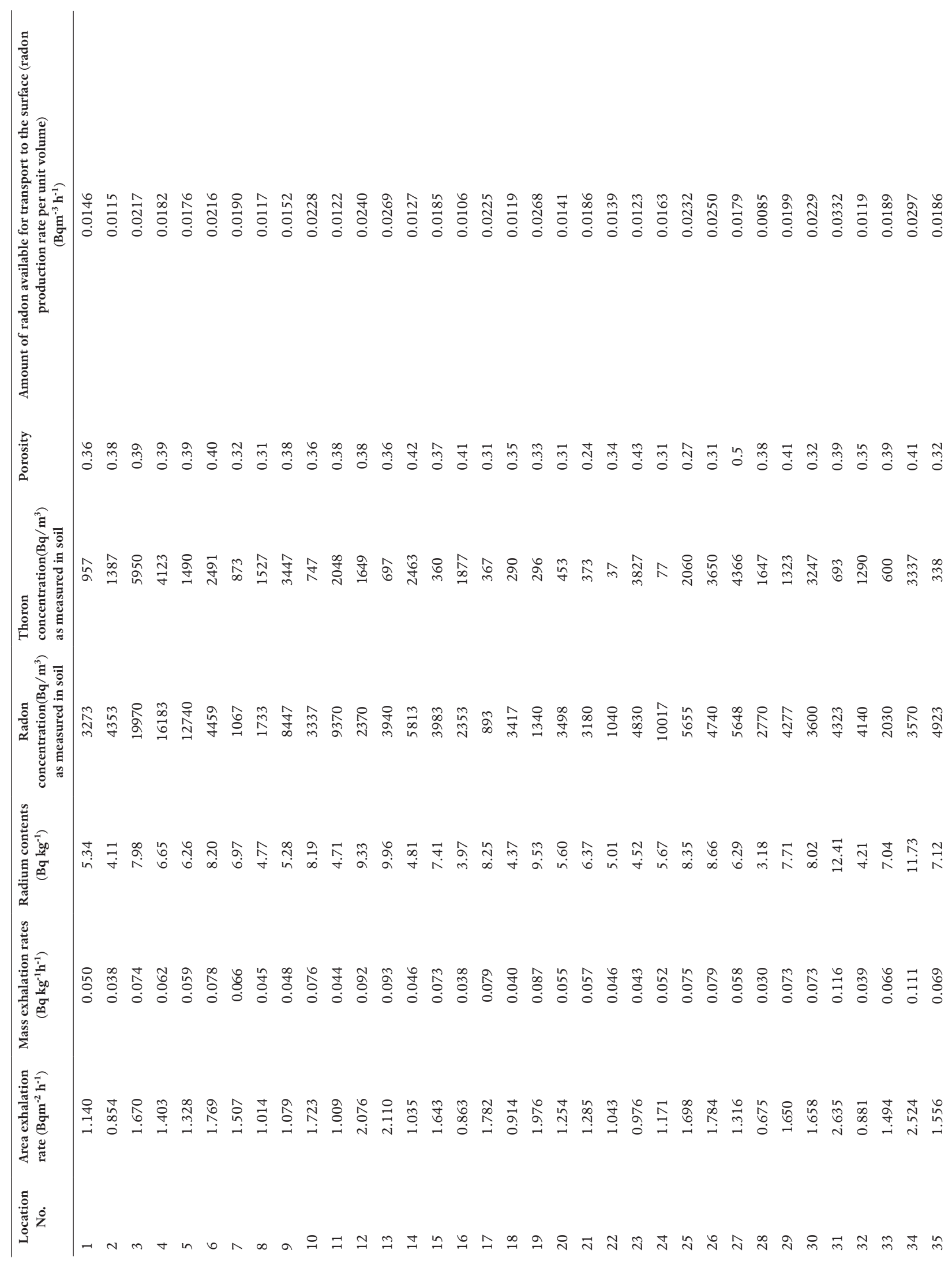




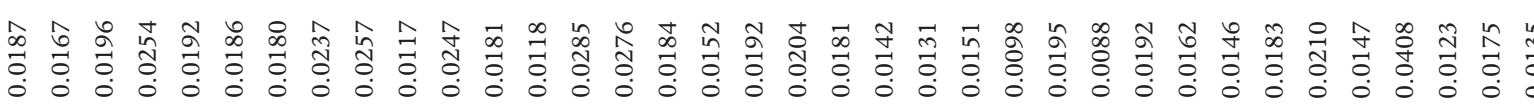

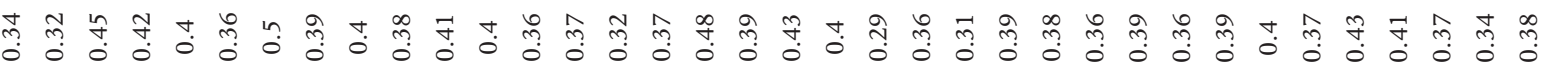

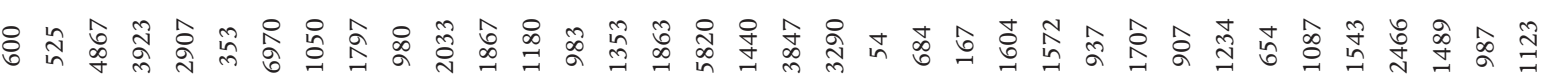

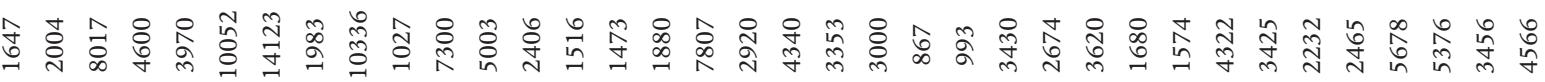

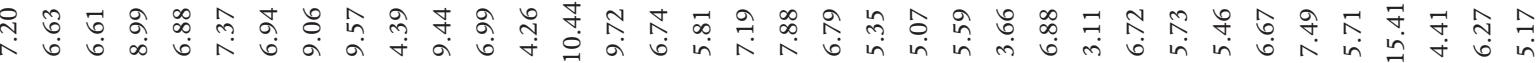

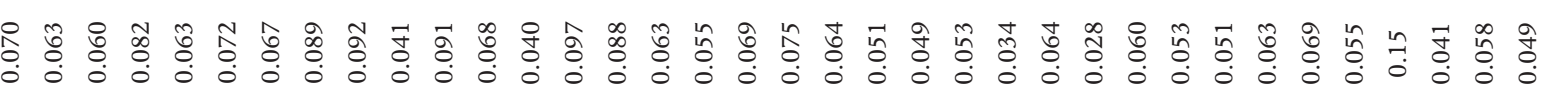

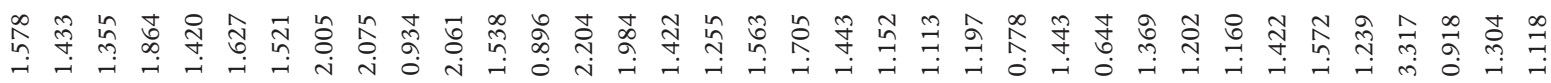

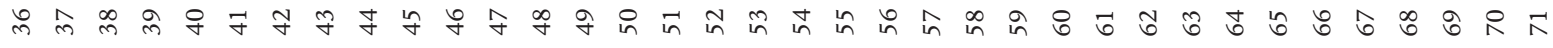




\begin{tabular}{lcccccccc}
\hline $\begin{array}{l}\text { Sr. } \\
\text { No. }\end{array}$ & Profile & $\begin{array}{c}\text { Porosity } \\
\text { (average) }\end{array}$ & $\begin{array}{c}\text { Average Area } \\
\text { Exhalation rates }\end{array}$ & $\begin{array}{c}\text { Average Radium } \\
\text { Contents }\end{array}$ & $\begin{array}{c}\text { Average value } \\
\left(\mathbf{B q} / \mathbf{m}^{3}\right)\end{array}$ & $\begin{array}{c}\text { Standard deviation } \\
\text { value }\left(\mathbf{B q} / \mathbf{m}^{3}\right)\end{array}$ \\
\cline { 6 - 9 } & & & & & Radon & Thoron & Radon & Thoron \\
\hline 1 & 1 to 6 & 0.39 & 1.36 & 6.42 & 10163 & 2733 & 7111 & 1947 \\
2 & 7 to 11 & 0.35 & 1.27 & 5.98 & 4791 & 1728 & 3862 & 1094 \\
3 & 12 to 16 & 0.39 & 1.55 & 7.10 & 3692 & 1409 & 1431 & 865 \\
4 & 17 to 22 & 0.35 & 1.46 & 6.81 & 2221 & 303 & 1267 & 143 \\
5 & 23 to 27 & 0.36 & 1.39 & 6.70 & 6178 & 2796 & 2190 & 1746 \\
6 & 28 to 34 & 0.38 & 1.65 & 7.76 & 3530 & 1734 & 856 & 1126 \\
7 & 35 to 37 & 0.33 & 1.52 & 6.98 & 2858 & 488 & 1797 & 135 \\
8 & 38 to 42 & 0.43 & 1.56 & 7.36 & 8152 & 3804 & 4165 & 2443 \\
9 & 43 to 47 & 0.40 & 1.72 & 7.89 & 5130 & 1545 & 3826 & 492 \\
10 & 48 to 51 & 0.36 & 1.63 & 7.79 & 1819 & 1345 & 432 & 377 \\
11 & 52 to 55 & 0.43 & 1.49 & 6.92 & 4605 & 3599 & 2216 & 1803 \\
12 & 56 to 60 & 0.35 & 1.14 & 5.31 & 2193 & 816 & 1184 & 744 \\
13 & 61 to 63 & 0.37 & 1.07 & 5.19 & 2291 & 1184 & 1152 & 453 \\
14 & 64 to 67 & 0.40 & 1.35 & 6.33 & 3111 & 1130 & 958 & 370 \\
15 & 68 to 71 & 0.38 & 1.66 & 7.82 & 4769 & 1516 & 993 & 668 \\
\hline
\end{tabular}

Table 2. Values of various soil parameters in different profiles (as shown in figure 2).

\begin{tabular}{|c|c|c|c|c|c|c|}
\hline \multicolumn{4}{|c|}{ Average values along MCT } & \multicolumn{3}{|c|}{ Average values along MBT } \\
\hline $\begin{array}{l}\text { Sr. } \\
\text { No. }\end{array}$ & $\begin{array}{l}\text { Serial no. of detectors } \\
\text { as in figure }\end{array}$ & $\begin{array}{l}\text { Radon con- } \\
\text { centration } \\
\left(\mathrm{Bq} / \mathrm{m}^{3}\right)\end{array}$ & $\begin{array}{c}\text { Thoron concen- } \\
\text { tration } \\
\left(\mathbf{B q} / \mathrm{m}^{3}\right)\end{array}$ & $\begin{array}{l}\text { Serial no. of detectors } \\
\text { as in figure }\end{array}$ & $\begin{array}{c}\text { Radon } \\
\text { concentration } \\
\left(\mathrm{Bq} / \mathrm{m}^{3)}\right.\end{array}$ & $\begin{array}{c}\text { Thoron } \\
\text { concentration } \\
\left(\mathrm{Bq} / \mathrm{m}^{3}\right)\end{array}$ \\
\hline 1 & $\begin{array}{l}\text { Monitoring station no. } \\
5,9,14,21,25,62 \text { very } \\
\text { near to MCT }\end{array}$ & 6253 & 1923 & $\begin{array}{c}\text { Monitoring station no. } \\
69,65,59,49,34,29,36 \\
35,37,54,46 \\
\text { Very near to MBT }\end{array}$ & 3801 & 1521 \\
\hline 2 & $\begin{array}{c}\text { Above serial no. } 1 \\
\text { (towards District Kullu) } \\
\text { station no. } 6,10,16,22, \\
26,61\end{array}$ & 6158 & 1297 & $\begin{array}{c}\text { Above serial no. } 1 \\
\text { (towards District Kullu } \\
\text { and MCT) } 68,64,60,48, \\
28,53,45\end{array}$ & 3113 & 1502 \\
\hline 3 & $\begin{array}{l}\text { Next nearest stations } \\
\text { above serial no. } 2 \text { from } \\
\text { Chail thrust }\end{array}$ & 2401 & 1661 & & & \\
\hline 4 & $\begin{array}{l}\text { Nearest Station from } \\
\text { chail thrust (towards } \\
\text { MBT) i.e. Below MCT } \\
\text { (Station No. 4, 8, 13, } \\
\text { 20, 24, 63) }\end{array}$ & 3258 & 1623 & $\begin{array}{c}\text { The stations below } \\
\text { MBT towards Palampur } \\
\text { thrust) } 70,66,56,50,30 \text {, } \\
55,47\end{array}$ & 3159 & 1698 \\
\hline 5 & $\begin{array}{l}\text { Next nearest stations } \\
\text { below chail thrust } \\
\text { (towards MBT) from } \\
\text { serial no. } 4\end{array}$ & 5217 & 2186 & $\begin{array}{l}\text { The stations below MBT } \\
\text { towards Palampur thrust. } \\
\text { Station No. } 71,67,57,51\end{array}$ & 2445 & 1303 \\
\hline
\end{tabular}

Table 3. Average values of radon-thoron concentration of a relative distance from MBT and MCT.

to very fine powder. $100 \mathrm{gm}$ of each powdered samples were placed at bottom of the cylinder of radius $3.5 \mathrm{~cm}$ and length $7.5 \mathrm{~cm}$ [Singh et al. 1997] (Figure 4). LR-115 type-II SSNTD $(0.015 \mathrm{~m} \times 0.015 \mathrm{~m})$ were placed at the top of the cylindrical enclosures and the container was sealed tightly for 90 days to establish the equilibrium. The detectors have been etched in $10 \mathrm{M}$
$\mathrm{NaOH}$ at $(60 \pm 5)^{\circ} \mathrm{C}$, for $90 \mathrm{~min}$, in a constant temperature water bath to enlarge the latent tracks and counted using optical microscope (400 X). The tracks are converted in to radon activity using the calibration factor of 0.02 tracks $/ \mathrm{cm}^{2} /$ day $=1 \mathrm{~Bq} / \mathrm{m}^{3}$ [Eappen and Mayya 2004]. The area and mass radon exhalation rate has been calculated using the formula [Amrani and 


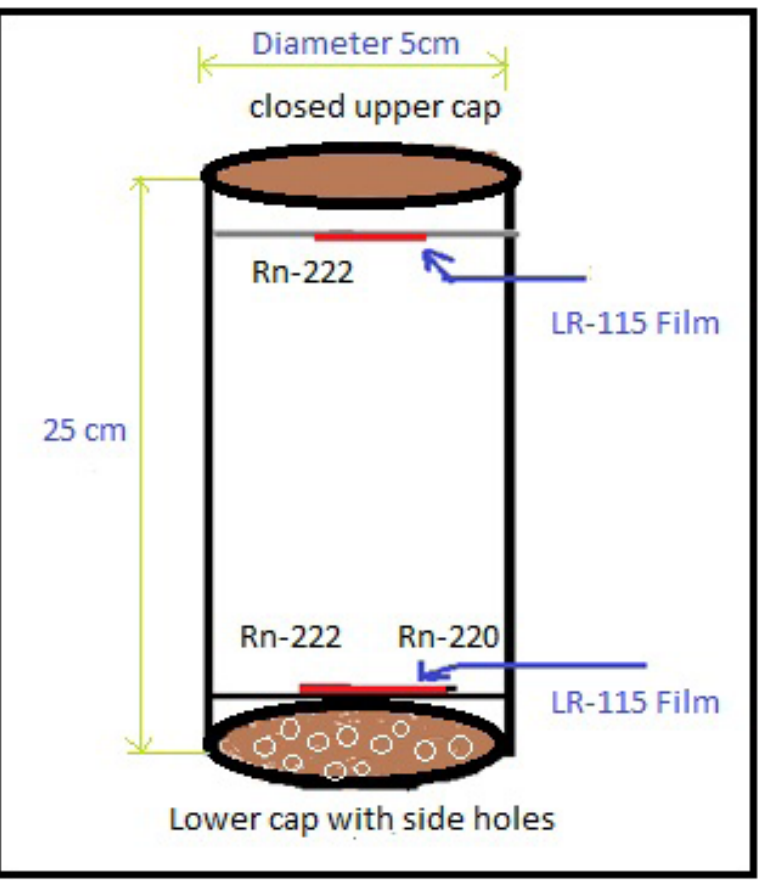

Figure 3. Sketch of radon-thoron discriminator (plastic cane with side cap including LR-115 films at the top of the cane and at the bottom of the cane) used in the present study.

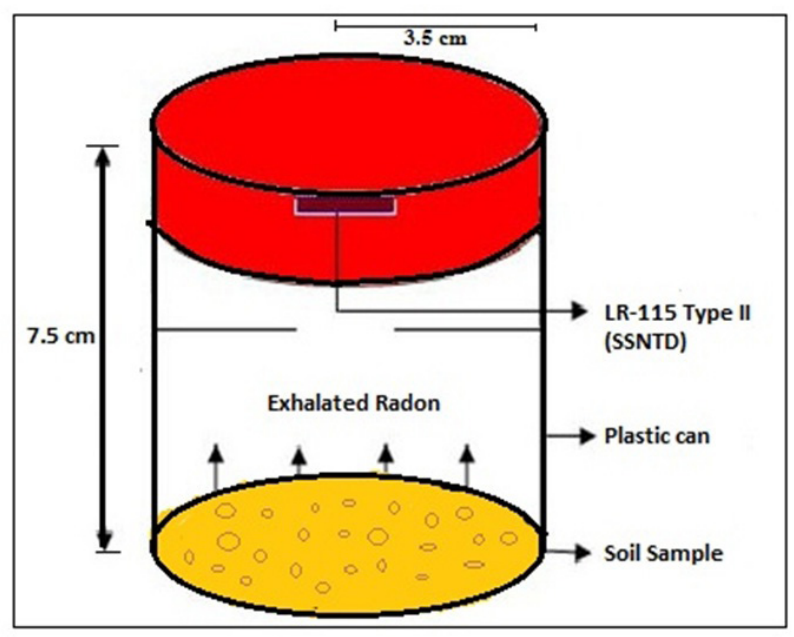

Figure 4. Schematic diagram of a container utilized for radon exhalation rate measurements in the present study.

Cherouati 1999]. Whereas the porosity $\eta$ of the soil is calculated using following formula $\eta=1-\rho$ bulk $/ \rho$ particle [Morgan et al. 2005].

\section{Results and discussions}

The radon and thoron concentration along with exhalation rates, radium contents, porosity and radon production rate per unit volume recorded at 71 locations in the study area are shown in the table 1 . The average concentration of radon and thoron gases in the study area has been found to be $4541 \mathrm{~Bq} / \mathrm{m}^{3}$ and $1778 \mathrm{~Bq} / \mathrm{m}^{3}$ within a range of $867-19970 \mathrm{~Bq} / \mathrm{m}^{3}$ and $37-6970 \mathrm{~Bq} / \mathrm{m}^{3}$, respectively. In order to identify possible threshold values of anomalous radon and thoron concentration, various statistical methods have been used by different authors in the past [Guerra et al. 2001, Walia et al. 2005, Fu et al. 2005]. In the present context, statistical threshold values of gas anomalies are fixed at average $(\mu)$ plus one standard deviation $(\sigma)$. Figures 5 and 6 shows the variation of radon and thoron concentration $\left(\mathrm{Bq} / \mathrm{m}^{3}\right)$ at different sampling locations in comparison to average $(\mu)$ and average + standard deviation value $(\mu+\sigma)$. The anomalous value of radon has been observed at 8 locations $(3,4,5,11,24,41,42 \& 44)$. The locations 3, 4, 5, $11 \& 24$ are close to MCT and locations $41 \& 42$ are close to MBT-II. The location 44 is close to local fault in the study area. The anomalous value of thoron has been observed in 12 locations ( 3,4 , $9,23,26,27,34,38,39,42,52 \& 54)$. The locations 3,4 , $9,23 \& 26$ are close to MCT and location 27 is close to MBT-I. Whereas locations $39 \& 42$ are close to MBT-II and locations 34, 38, $52 \& 54$ are close to the local fault in the study area. Anomalies in measurement of radon and thoron concentration are more along and across MCT than MBT and any fault system. More anomalies have been found in measurement of thoron concentrations. It may be due to shallower gas source in the study area [Yang et al. 2005, Kumar et al. 2013b].

The area and mass exhalation rates of radon have been calculated for each site and have been reported in Table 1 . The average value of area and mass exhalation rates have been found to be $1.46 \mathrm{~Bq} / \mathrm{m}^{2} \mathrm{~h}$ and 0.064 $\mathrm{Bq} / \mathrm{kg} \mathrm{h}$ with a variation of $0.644 \mathrm{~Bq} / \mathrm{m}^{2} \mathrm{~h}$ and 0.028 $\mathrm{Bq} / \mathrm{kg}$ h, respectively at location number 61 to 3.317 $\mathrm{Bq} / \mathrm{m}^{2} \mathrm{~h}$ and $0.15 \mathrm{~Bq} / \mathrm{kg} \mathrm{h}$ respectively at location number 68 . The radium content of the soil has been ranged between $3.11-15.41 \mathrm{~Bq} / \mathrm{kg}$ with an average value for the area as $6.84 \mathrm{~Bq} / \mathrm{kg}$.

The porosity of the soil has been found to vary with a minimum (0.24) at location 21 to a maximum of 0.5 at two locations 27 and 42 with an average of 0.37 at five locations labelled with numbers $15,49,51,66$, 69. The correlation factor of 0.59 has been observed between radon and thoron concentration of the study area and a good correlation (0.64) between thoron and porosity has also been detected. Similar kind of correlation has been reported by Al Jarallah et al. [2005] in a study related to construction materials (especially granite) used in Saudi Arabia.

In this study very less correlation (0.03) between porosity and amount of radon available for transport to the surface has been recorded. However, at the sampling sites 51, 62 and 65 the values of radium contents, porosity and amount of radon available for transport to the surface recorded are $6.74 \mathrm{~Bq} \mathrm{~kg}^{-1}, 0.37,0.0184$ 
$\mathrm{Bqm}^{-3} \mathrm{~h}^{-1}, 6.72 \mathrm{~Bq} \mathrm{~kg}^{-1}, 0.39,0.0192 \mathrm{Bqm}^{-3} \mathrm{~h}^{-1}$ and 6.67 $\mathrm{Bq} \mathrm{kg}^{-1}, 0.4,0.0183 \mathrm{Bqm}^{-3} \mathrm{~h}^{-1}$ respectively. For sampling sites 17 and 18 these values are $8.25 \mathrm{~Bq} \mathrm{~kg}^{-1}, 0.31,0.022$ $\mathrm{Bqm}^{-3} \mathrm{~h}^{-15}$ and $8.02 \mathrm{~Bq} \mathrm{~kg}^{-1}, 0.32,0.0229 \mathrm{Bqm}^{-3} \mathrm{~h}^{-1}$ and at sampling sites 57 and 71 values are $5.17 \mathrm{~Bq} \mathrm{~kg}^{-1}, 0.38$, $0.0135 \mathrm{Bqm}^{-3} \mathrm{~h}^{-1}$ and $5.07 \mathrm{~Bq} \mathrm{~kg}^{-1}, 0.36,0.0131 \mathrm{Bqm}^{-3}$ $\mathrm{h}^{-1}$. These observations shows that if the radium contents of some soil samples are comparable then with the porosity of the soil radon transport factor to surface will increase. Also, if there is secondary porosity in any region due to presence of fault systems then permeability/ emanation factor of the soil will increase, which will further increase the radon transport to surface [Cinti et al. 2009, Ciotoli et al. 2016].

The average value of radon, thoron along with average exhalation rates, average radium contents and average porosity in different profiles (as shown in fig 2) has been reported in table 2. Profiling 1, 2, 3, 4, 5 and 13 has been made along and across the main central thrust (MCT) and profiling 6, 7, 8, 9, 10, 11, 12, 14 and 15 has been made along and across MBT and local faults in the study area. The radon has been found to vary in the range of $1680-12740 \mathrm{Bqm}^{-3}$ with an average of $6253 \mathrm{Bqm}^{-3}$ along the MCT. The concentration of radon and thoron at MBT has varied in the range of $1516-7300 \mathrm{Bqm}^{-3}$ with an average value of $3980 \mathrm{Bqm}^{-}$ ${ }^{3}$ and 338-3847 $\mathrm{Bqm}^{-3}$ with an average value of 1621 $\mathrm{Bqm}^{-3}$, respectively. The values of radon concentration are decreasing by factor of 1.01 to 2.56 on both side of MCT and MBT, while thoron concentrations are decreasing by factor of 1.01 to 1.5 on moving distance of 2 to $3 \mathrm{~km}$ from MBT and MCT, with exceptions at some stations towards Palampur thrust, this may be due to the fact that there exist Numbers of local faults in between MBT and MCT.

The radon and thoron concentrations have been detected to increase with a movement from Chail thrust (MCT) to MBT in the Jogindernagar region that may be attributed to the geological stress and strain in this region. The concentrations of radon and thoron along the MBT have been found lesser than that of the MCT. This may be due to the reason that MCT is under more geological stress and strain as compared to the MBT.

The average values of soil radon measured along the MCT (Main central thrust) in the profiles 1, 2, 3, 4, 5 and 13 have been recorded as $10163 \mathrm{~Bq} / \mathrm{m}^{3}, 4791 \mathrm{~Bq} /$ $\mathrm{m}^{3}, 3692 \mathrm{~Bq} / \mathrm{m}^{3}, 2221 \mathrm{~Bq} / \mathrm{m}^{3}, 6178 \mathrm{~Bq} / \mathrm{m}^{3}, 2291 \mathrm{~Bq} /$ $\mathrm{m}^{3}$ whereas the average thoron concentration in the same profiles has been observed as $2733 \mathrm{~Bq} / \mathrm{m}^{3}, 1728$ $\mathrm{Bq} / \mathrm{m}^{3}, 1409 \mathrm{~Bq} / \mathrm{m}^{3}, 303 \mathrm{~Bq} / \mathrm{m}^{3}, 2796 \mathrm{~Bq} / \mathrm{m}^{3}, 1184 \mathrm{~Bq} /$ $\mathrm{m}^{3}$. The profile 1 has exceptionally high average values because the presence of sling zones along this profile. The radon concentrations have been noticed to decrease from Jogindernagar to Mandi along MBT-1 due to the decrease in porosity of the soil. The same trend has been observed when the observer has moved along the profile $8,11,10$ that may be attributed to the cross presence of other faults systems.

The decreasing trend of radon and thoron concentrations has been observed along the route followed through the profile 15, 3 and 4 that may be due to the higher radon exhalation rates, radium contents and more or less due to porosity of soil in the area of profile 15 than in soil of profiles 3 and 4 . The slight elevation in the concentration along the sampling sites of profile 6 and 7 has been spotted that may have been caused by the presence of secondary fault systems (Sundernagar fault)in the vicinity of Sundernagar [Mahajan et al., 2010] and may be due to high porosity in the soil of profile $6(0.38)$ and profile 7 (0.33) and relatively high values of radon exhalation rates $1.65 \mathrm{~Bq} / \mathrm{m}^{2} \mathrm{~h}$ (in profile 6 ) and $1.52 \mathrm{~Bq} / \mathrm{m}^{2} \mathrm{~h}$ (in profile 7) and high values of radium contents $7.76 \mathrm{~Bq} /$ $\mathrm{kg}$ (in profile 6) and $6.98 \mathrm{~Bq} / \mathrm{kg}$ (in profile 7).

The results also shows that the MBT and MCT of Himalayan region is more active than Turkish faults as reported by Sac et al. [2011] as the values of soil radon concentration measured are more as compared to the values measured near the fault in the western Turkey. However the values of soil radon concentration observed in the present study have been found to be lower as compared to the values measured in complex tectonic and seismic Tangshan area of northern China (where earthquake Ms 7.8 was occurred in 1976) as reported by Li et al. [2013]. The average values of radon and thoron concentration in Dharamshala near MBT and MCT in Himachal Pradesh were $5992 \mathrm{~Bq} / \mathrm{m}^{3}$ and Thoron values of $901 \mathrm{~Bq} / \mathrm{m}^{3}$ [Kumar et al. 2013b]. The trend in observed value of radon in Dharamshala region of Himachal Pradesh are similar to the present study, however the thoron values in Mandi region are found to be almost double than in Dharamshala region.

The values of Radon concentration are decreasing by factor of 1.01 to 2.56 on both side of MCT and MBT, while Thoron concentrations are decreasing by factor of 1.01 to 1.5 on moving distance of 2 to $3 \mathrm{~km}$ from MBT and MCT, with exceptions at some stations towards Palampur thrust (Table 3), this may be due to the fact that there exist numbers of local faults in between MBT and MCT.

The present study may also be helpful to study 


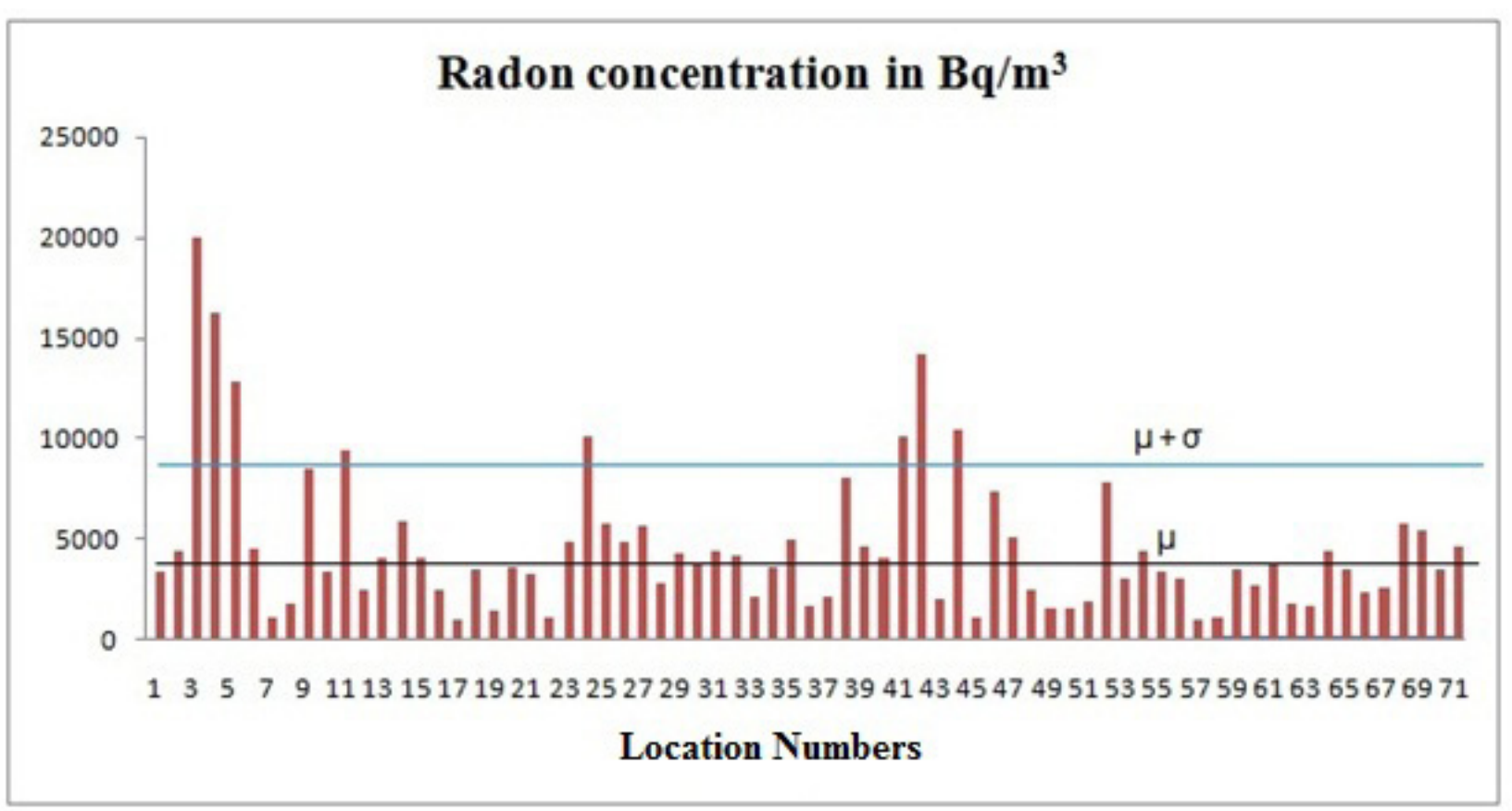

Figure 5. The variation of radon concentration $\left(\mathrm{Bq} / \mathrm{m}^{3}\right)$ at different measuring stations in comparison to average $(\mu)$ and average + standard deviation value $(\mu+\sigma)$.

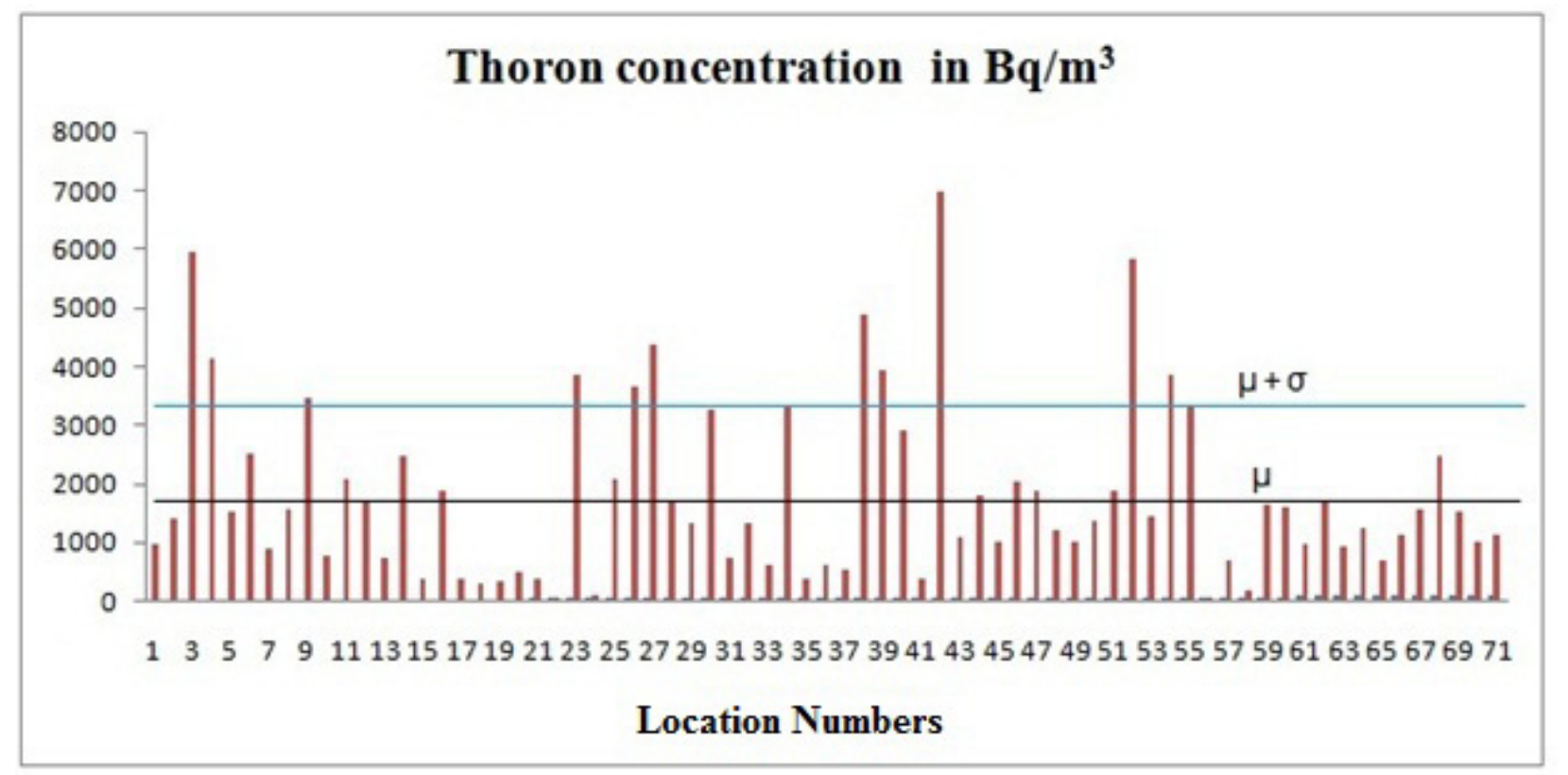

Figure 6. The variation of thoron concentration $\left(\mathrm{Bq} / \mathrm{m}^{3}\right)$ at different measuring stations in comparison to average $(\mu)$ and average + standard deviation value $(\mu+\sigma)$.

other natural features of study area like geothermal potential and ground water reservoirs, since high thermal energy flow with good thermal gradient have been observed by various researchers in NW Himalaya. This heat flow may be due the melting and reductions of intrusive granites near to MBT and MCT in Mandi area and presence of uranium, thorium and potassium contents in the soil texture [Rao et al. 1976, Das et al. 1979, Walia et al. 2005]. These reductions in basic strata of area may create faults which are the cause of secondary porosity and hence increase in the gases like Radon and thoron along with thermal energy fluids with a path of flow of water to the surface. The Beas valley, Uhl valley and region from Jogindernagar to Mandi have potentially good source of ground water. Thus elevated levels of radon and thoron gases in seismically active and faulty area may be used detect secondary porosity, so the monitoring of these radio nuclides will further help to study the other gases transport through porous medium of the soil.

\section{Conclusions}

The radon-thoron measurement in soil, measurement of radon exhalation rates and radium contents of 
Mandi district, Himachal Pradesh, NW Himalaya, India has been measured using the passive detectors LR-115 type-2 films. The anomalous value of radon-thoron has been reported along and around MCT, MBT and local faults in the study area. Radon concentration along MCT have been found higher than that along MBT, this may be due to the reason that MCT is under more geological stress and strain as compared to MBT. More anomalies have been recorded in the measurement of thoron concentration. The thoron concentrations values are very low at some places; this may be due to presence of deeper source in earth at these places. Good correlation between porosity and thoron has been recorded in this study, which shows presence of local fault in the area. Also it has been found that area exhalation rates, mass exhalation rates depends up on the radium contents of the soil. The porosity and seepage of radon and thoron may be helpful to study ground water potential and its reservoir in any region. The elevated levels of radon and thoron at certain places can be associated to the presence of secondary porosity in the soil texture. Secondary porosity due to fracturing of basic strata may provide the easy pathway for upward movement of geothermal fluids.

Acknowledgements. Authors are thankful to the people of the study area for their help and cooperation during the field work. One of the authors (Gulshan Kumar) is thankful to the Principal, Govt. College Sarkaghat, for his cooperation during the work and providing the lab facilities. We are also thankful to anonymous reviewers for their valuable suggestions for improvement of the manuscript.

\section{References}

Al-Jarallah M., F. Ur-Rehman, M.S. Musazay, A. Aksoy (2005). Correlation between radon exhalation and radium contents in granite samples used as construction material in Saudi- Arabia. Radiat. Meas., 40(2), 625-629.

Al-Tamimi, M.H., K.M. Abumurad (2001). Radon concentration along faults in north of Jordan. Radiat. Meas., 34, 397-400.

Amrani, D., D.E. Cherouati (1999). Radon exhalation rate in building materials using plastic track detectors, J. Radioanal. Nucl. Chem., 242(2), 269-271.

Bajwa, B.S., N. Sharma, V. Walia, H.S. Virk (2003). Measurements of natural radioactivity in some water and soil samples of Punjab state, India. Indoor and Built Environment, 12, 357-361.

Chandrasekharam, D., M.A. Alam, A. Minissale (2003). Geothermal resource potential of Himachal Pradesh, India. International geothermal conference, Reykjavik, Sept, 2003 session \# 4, 15-20 p.

Chandrasekharam, D., M.A. Alam, A. Minissale (2005).
Geothermal Discharge at Manikaran Himachal Pradesh, India. Proceedings world geothermal congress, 2005 Antalya, Turkey, 24-29 April 2005.

Chandrasekharam, D., V. Chandrasekhar (2008). Geothermal resources in India: Possibilities for direct use in the Himalayas. Presented at the workshop for decision makers on direct heating use of geothermal resources in Asia, Organised by UNUGTP, TBLRREM and TBGMED, in Tianjin, China, 11-18 May, 2008.

Chi-Yuen, W., S. Yao-lin, Z. Wen-hu (1982). Dynamic uplift of the Himalaya. Nature 298, 553-556.

Choubey, V.M., K.K. Sharma, R.C. Ramola (1997). Geology of radon occurrence round Jari in Parvati Valley, Himachal Pradesh, India. J Environ. Radioact., 34(2), 139-147.

Choubey, V.M., P.K. Mukherjee, B. S. Bajwa, V. Walia (2007). Geological and Tectonic Influence on Water-Soil-Radon Relationship in Mandi - Manali Area, Himanchal Himalaya. Environmental Geology, 52, 1163-1171.

Chyi, L.L., T.J. Quick, T.F. Yang, C.H. Chen (2005). Soil gas radon spectra and earthquakes, Terrestrial, Atmospheric and Oceanic Sciences, 16,763-774.

Cinti, D., L. Pizzine, N. Voltattorni, F. Quattrocchi, V. Walia (2009). Geochmistry of thermal fluids along faults segments in the Beas and Parvati Valley (north-west Himalaya Himachal Pradesh) and Sohana town(Haryana), India. Geochemical journal, 43,65-76.

Ciotoli, G., A. Sciarra, L. Ruggiero, A., Annunziatellis, S. Bigi, (2016). Soil gas geochemical behaviour across buried and exposed faults during the 24 August 2016 Central Italy earthquake. Annals of Geophysics, 59, fast track 5, 2016; DOI: 10.4401,ag-7242.

Ciotoli, G., M. Guerra, E. Lombardi, E. Vittori (1998). Soil gas survey for tracing seismogenic faults: A case study in the Fucino basin, central Italy. J.Geophys. Res., 103, 23781-23794.

Darko, G., G. Faanu, O. Akoto, A. Acheampong, E.J. Goode, O. Gyamfi (2015). Distribution of natural and artificial radioactivity in soils, water and tuber crops, Environ. Monit. and Assess., 187, 339.

Das, G.R.N, T.N. Parthasarthy, P.C. Taneja (1979). Uranium mineralisation in the politic schists in the Kullu Himalaya and its probable origin. Proc. Indian Sci. Acad.37,267-276.

Eappen, K.P., Y.S. Mayya (2004). Calibration factors for LR-115(Type-II) based radon thoron discriminating dosimeter. Radiat. Meas., 38, 5-17.

Etiope, G. and S. Lombardi (1995). Evidence for radon transport by carrier gas through faulted clays in 
Italy. J. Radioanal. Nucl. Chem., 193, 291-300.

Fu, C.C., T.F Yang, V. Walia, C.H. Chen (2005). Reconnaissance of soil gas composition over the buried fault and fracture zone in southern Taiwan, Geochem. J.,39, 427-439.

Gansser, A. (1964). Geology of Himalayas, Interscience, New York.

Geology and Mineral Resources of Himachal Pradesh (2012). Miscellaneous Publication no. 30: Part-17, Geology and mineral resources of the states of India, Geological Survey of India.

Georgy, C., Z. Rafael, B. Ivan (2015). Radon monitoring in groundwater and soil gas of Sakhalin Island, J Geosci.and Environ.Protect.,3(5), 48-53.

Giggenbach, W.F., R. Gonfiantini, B.L. Jangi, A.H. Truesdell (1983). Isotope and chemical composition of Parvati valley geothermal discharges, North west Himalaya, India, Geothermics 12, 199-222.

Guerra, M. and S. Lombardi (2001). Soil-gas method for tracing neotectonic faults in clay basins: The Pisticci field (Southern Italy), Tectonophysics, 339, 511-522.

Gunderson, L.C.S., G.M. Reimer, S.S. Agard (1998). The correlation between geology, radon in soil gas and indoor radon in the Reading Prong. In: Marikos, M. (Ed.), Proceedings of the GEORAD conference, geological causes of radionuclides anomalies, Missouri Department of Natural Resources, Special Publication no. 4, 99-111.

Gupta, G.K. (1996). Hydrogeology and hydrochemistry of Beas valley geothermal system, Kullu district Himachal Pradesh, Geol survey of India 45, 249-256.

Han, X., Y. Li, J. Du, X. Zhou, C. Xie, W. Zhang (2014). $\mathrm{Rn}$ and $\mathrm{CO}_{2}$ geochemistry of soil gas across the active fault zone in the capital area of china, Nat. Hazards and Earth Syst. Sci., 14, 2803-2815.

Igarashi, G., S. Saeki, N. Takahata, K. Sumikawa, S. Tasaka, Y. Sasaki, M. Takahashi and Y. Sano (1995). Groundwater radon anomaly before the Kobe earthquake in Japan, Science, 269, 60-61.

Jaishi, H.P., S. Singh, R.P. Tiwari, R.C. Tiwari (2014). Analysis of soil radon data in earthquake precursory studies. Ann. Geophys., 57(5), S0544.

Jashank, M.,S.J. Gupta, J. Nair, (2014). Development of Radon Gas Sensor to Monitor: The Precursors of Earthquake. IOSR J. of Engg., 4, 10-15.

Koike, K., T. Yoshinaga, T. Ueyama and H. Asaue (2014). Increased radon-222 in soil gas because of cumulative seismicity at active faults.Earth Planet and Space, 66, 57.

Kumar, G., A. Kumar, V. Walia, J Kumar, V. Gupta, T.F.
Yang, S. Singh, B. S. Bajwa, (2013b). Soil gas radon -thoron monitoring in Dharamshala area of North-West Himalayas, India using solid state nuclear track detectors. J. of Earth Syst. Sci.,122 (5),1295-1301.

Kumar, A., S. Singh, S. Mahajan, B. S. Bajwa, R. Kalia and S. Dhar (2009). Earthquake precursory studies in Kangra valley of north-west Himalayas, India, with special emphasis on radon emission, Appl. Radiat. And Isot., 67, 1904-1911.

Kumar, A., V. Walia, S. Singh, B.S. Bajwa, S. Mahajan, S. Dhar and T.F. Yang (2013a). Earthquake precursory studies at Amritsar, Punjab, India using radon measurement techniques. Inter. J. of Phys Sci, 7(42), 5669-5677.

Li Y., J. Du, X. Wang, X. Zhou, C. Xie, Y. Cui (2013). Spatial variations of soil gas geochemistry in Tangshan area of northern china. Terr. Atmos. Ocean. Sci., Vol.24.No 3,323-332.

Mahajan, S., V. Walia, B. S. Bajwa, A. Kumar, S. Singh, N. Seth, S. Dhar, G.S. Gill and T.F. Yang (2010). Soilgas radon/helium surveys in some neotectonic areas of NW Himalayan foothills, India; Nat. Hazards Earth Syst. Sci., 10, 1221-1227.

Morgan, R.P.C. (2005). Soil erosion and conservation 3rdedn, Blackwell Publishing Ltd. USA.

Pereira, A. J. S. C., M. M. Godinho, L. J. P. F. Neves (2010). On the influence of faulting on small-scale soil-gas radon variability: A case study in the Iberian Uranium Province, J. Environ. Radioact., 101, 875-882.

Piersanti, A., V. Cannelli, G. Galli, (2015). Long term continuous radon monitoring in a seismically active area. Ann. Geophys., 58(4), S0437.

Poelchau, H.S., D.R. Baker, T.H. Hantschal, B. Horsefield, B.C. Wygrala (1997). Basin simulation and the design of the conceptual basin model. In: Welre $\mathrm{DH}$, Horsefield $\mathrm{B}$, Baker DR(eds) Petroleum and Basin evaluation. Springer Berlin, pp 36-41.

Quattrocchi, F., G. Di Stefano, L. Pizzino, F. Pongetti, G. R. Scarloto, P. Sciacca, U.G. Urbini (2000). Geochemi. C al Monitoring system II Prototype (GMS II) installation at the "Aqua Di Fesa” well, within the Etna Region : First data, J.Volcanol.andGeoth. Res., 101, 273-306.

Rao, R.U.M., G.V. Rao. N. Hari (1976). Radioactive heat generation and heat flow in the Indian shield. Earth Planet Sci. Lett. 30, 57-64.

Sac, M.M., C. Harmansah, B. Camgoz, H. Sozbilir (2011). Radon Monitoring as the Earthquake Precursor in Fault Line in Western Turkey.Ekoloji 20, 93-98. 
Scholz, C.H., L.R. Syke, Y.P. Aggarwal (1973). Earthquake prediction: a physical basis, Science, 181, 803-809.

Shanker, R (1988). Heat flow of India and discussion on its geological and economic significance. Ind. Min. 42,89-110.

Sharma, V.P. (1977). Geology of Kullu Rampur belt, Himachal Pradesh. Mem. Geol. Soc. India, 106, 235-407.

Singh, A.K., P. J .Jojo, A.J. Khan, R. Prasad and T.V. Ramachandran(1997). Calibration of track detector and measurement of radon exhalation rates from soil sample, Radiat. Prot. Environ.,20,129.

Singh, B., S. Singh,B.S. Bajwa, J. Singh, A. Kumar (2011). Soil gas radon analysis in some areas of Northern Punjab, Environ. Monit. and Assess., 174, 209-217.

Singh, S., D.K. Sharma, S. Dhar. and S.S. Randhawa (2006). Geological significance of soil gas radon: A case study of Nurpur area, district Kangra, Himachal Pradesh, India,Radiat. Meas., 41(4), 482-485.

Singh, S., A. Kumar, B.S. Bajwa, S. Mahajan, V. Kumar and S. Dhar (2010). Radon monitoring in soil gas and ground water for earthquake prediction study in NW Himalaya, India.Terrest., Atmos. and Ocean. Sci., 21(4), 685-695.

Singh, S., M. Kumar, R.K. Mahajan, (2005). The study of indoor radon in dwellings of Bathinda district, Punjab, India and its correlation with uranium and radon exhalation rate in soil.Radiat. Meas., 39(5), 535-542.

Szabo, K.Z., G. Jordan, A.H.C. Szabo (2013). Dynamics of soil gas radon concentration in highly permeable soil based on long term high temporal resolution observation series. J. Environ. Radioact., 124, 74-83.

Toutain, P., J.C. Boubro (1999). Gas geochemistry and Seismotectonic: a review. Tectophysics, 304, 1-24.

Virk H.S., V. Walia (2000). Radon/ Helium monitoring in thermal springs and earthquake prediction, Publ. of the centre of advanced study in Geol. 7.106-107.

Walia, V., B.S. Bajwa, H. S. Virk (2003). Radon monitoring in ground water of some areas of Himachal Pradesh and Punjab states, India. Jour. of Environment Monitoring, 5, 122-125

Walia, V., H.S. Virk, T.F. Yang, S. Mahajan, M. Walia and B.S. Bajwa (2005). Earthquake prediction studies using radon as a precursor in NW- Himalaya India: a case study. Terr. Atmos. Ocean. Sci.,16(4) 775-804.

Walia, V., T.F. Yang, S.J. Lin, A. Kumar, C.C. Fu, J.M. Chiu, H.H. Chang, K.L. Wen and C. H. Cheng (2013). Temporal variation of soil gas compositions for earthquake surveillance in Taiwan. Radiation Measurements, 50, 154-159.

Yang, T.F., V. Walia, L. L. Chyi, C.C. Fu, C.H. Chen, T.K. Liu, S. R. Song, C.Y. Lee and M. Lee (2005). Variations of soil radon and thoron concentrations in a fault zone and prospective earthquakes in SW Taiwan, Radiat. Meas., 40, 496-502.

Yang, T.F., H.Y. Wen, C.C. Fu, H.F. Lee, T.F. Lan, A.T. Chen, W.L. Hong, S.J. Lin and V. Walia (2011). Soil radon flux and concentrations in hydrothermal area of the Tatun Volcano Group, northern Taiwan, Geochem. J., 45, 483

\footnotetext{
${ }^{\star}$ Corresponding author: Mukesh Kumar Department of Physics, Lovely Professional University, Phagwara, Punjab, India.

e-mail: moka.esh9@gmail.com,mukesh.kumar@lpu.co.in by Istituto Nazionale di Geofisica e Vulcanologia. All rights reserved
} 